\title{
The Ideology of the Postcolonial State in Indian Constituent Assembly Debates (1946-50)*
}

\author{
Mohammad Shahabuddin \\ Professor of International Law \& Human Rights, Birmingham Law School, University \\ of Birmingham, UK
}

\section{INTRODUCTION}

Whereas the majority of states, including Western liberal democracies, are not completely immune from ethno-nationalism, postcolonial states are more vulnerable to this phenomenon for a variety of reasons, such as the continuation of the colonial political order, the class character of the economic organisation, and the hegemony of nation-building projects. In most cases, nationalist elites address the problem of ethnonationalism in general and minorities in particular by identifying the "postcolonial state' itself as an 'ideology', claiming that the unified national state and its liberal constitutional structure will solve the trouble of ethnic parochialism and, hence, the problem of minorities.

Here, I rely on John Thompson's notion of 'ideology' as a set of ways in which ideas and meanings help create and sustain relations of domination through a series of general modes of operation and strategies of symbolic construction. These include legitimation, dissimulation, unification, fragmentation, and reification. ${ }^{1}$ By legitimation, Thompson means the process by which authority comes to seem to be valid and appropriate. Once the suppressed groups accept the legitimacy of the oppressor's authority, the relations of domination become perpetual. Dissimulation refers to a process whereby relations of domination are established and sustained by being concealed, denied, obscured, or glossed over. Thompson's third mode of ideological operation is unification - the process of constructing a form of symbolic unity which embraces individuals in a collective identity, irrespective of the differences and divisions that may separate them. The fourth mode of ideological operation, in contrast, is fragmentation. Here relations of domination are maintained by fragmenting groups who are seen as potential threats to the dominant group. And finally, Thompson's fifth mode of ideological operation is reification: representing a transitory, historical state of affairs as if it were permanent, natural, and timeless.

Within this framework of 'ideology', in this paper I demonstrate that the ideological function of the postcolonial state in the form of the 'national' and 'liberal' state inflicts

* Ideas presented in this paper have been elaborated and published in Mohammad Shahabuddin, Minorities and the Making of Postcolonial States in International Law (Cambridge University Press 2021) 56-85.

1 See generally, John B. Thompson, Ideology and Modern Culture: Critical Social Theory in the Era of Mass Communication (Polity Press 1990). 
various forms of marginalisation on minorities but simultaneously justifies the oppression in the name of national unity and liberal principles of equality and nondiscrimination, respectively. In asserting faith in the healing power of the postcolonial state, the nationalist elites conveniently avoid crucial questions as to the continuation of the colonial political order, the class character of the economic organisation, and the hegemony of nation-building projects - factors that lead to ethno-nationalism in the first place. In other words, the idea that the postcolonial state itself will solve the minority problem obscures and glosses over the real reasons for the problem and shifts attention to issues that help maintain asymmetric power relations between the minority and the majority. In this way, the postcolonial state performs the ideological function of suppressing minority group identities, but simultaneously obscures and validates further marginalisation of minorities.

To substantiate this argument, I use historical examples: the discourse used in Indian Constituent Assembly debates between 1946 and 1950 to discuss minority rights. More specifically, I demonstrate how the ideological function of the postcolonial 'national' and 'liberal' state supressed the question of the protection of religious minorities in Indian Constituent Assembly debates.

\section{THE POSTCOLONIAL 'NATIONAL' STATE}

The ideology of the postcolonial 'national' state is premised upon a homogenous national identity that absorbs all ethno-cultural differences. Given the long-term goal of assimilation and homogenisation, it is expected that the minority problem would wither away. At the same time, the process of diminishing all meaningful ethnocultural diversity and reducing such diversity to a token showcase element imposes the majoritarian identity on the entire nation. In other words, the majoritarian culture, belief system, and cultural codes come to synonymise the 'national' identity in the name of nation-building and homogenisation. The ideology of the postcolonial 'national' state, presented as a solution to the minority problem, thus in fact acts as a tool to perpetuate the dominance of the majority group over the minority in all political and cultural domains of the new state, leaving the minority at the mercy of the majority on vital political and economic issues.

In the case of India, the Constituent Assembly debates clearly demonstrate this pattern of the depiction of the 'national' state as an ideology to deal with the problem of minorities. The Assembly was created under the Cabinet Mission Plan of 16 May 1946 for the purpose of 'the cession of sovereignty [from Britain] to the Indian people on the basis of a constitution framed by the Assembly'. ${ }^{2}$ The Plan contained proposals for the constitutional future of India against the backdrop of the ongoing political rivalry - mainly between the Indian National Congress and the Muslim League - on the future of postcolonial India itself. Although the Plan rejected the League demand for a separate state for Muslims, i.e. Pakistan, it proposed a federal structure for the nascent

2 Initiated by the then British premier Clement Attlee, the Mission consisted of Lord PenthickLawrence, Secretary of State for India, Sir Stafford Cripps, President of the Board of Trade, and A.V Alexander, First Lord of Admiralty. 
Indian state with the assertion that such a structure would ensure adequate safeguard for religious minorities. The Plan also stipulated that the cession of power from Britain to India would be conditional upon 'adequate provision for the protection of minorities'. ${ }^{3}$ Even though the Congress elites were duty bound to set the framework of the future constitution of India within the remit of the Cabinet Mission Plan, there was a general sense of agreement and acceptance among them that the future constitution of India must incorporate provisions for minority protection. For example, the resolution on aims and objectives of the constitution (popularly known as the 'objective resolution'), moved by Jawaharlal Nehru and described by him as the core philosophy behind the constitution of India, proclaims that 'adequate safeguards shall be provided for minorities, backward and tribal areas, and depressed and other backward classes'. ${ }^{4}$ An Advisory Committee and afterwards a sub-committee on minorities thereunder were also formed in line with the Cabinet Mission Plan to prepare a report outlining provisions for the protection of minorities. ${ }^{5}$

In its draft report of August 1947, in the same month India was partitioned to create Pakistan, the Advisory Committee outlined a series of special safeguards for minorities in addition to a number of fundamental rights for all citizens. As the Chairman of the Committee and the first Deputy Prime Minister Sardar Vallabhbhai Patel informed the Assembly:

[the fundamental rights] cover a very wide range of the rights of minorities which give them ample protection; and yet there are certain political safeguards which have got to be specifically considered. An attempt has been made in this report to enumerate those safeguards [...] such as representation in legislatures $[\ldots]^{6}$

As a result, although the heavily criticised British policy of separate electorates for different religious groups was dismantled, the draft report proposed reserving seats in the parliament in proportion to the population of the minorities for a fixed period of ten years. ${ }^{7}$ The Committee also mandated that a certain proportion of public service roles be reserved for members of certain communities for the same length of time. ${ }^{8}$ The draft report also provided for an administrative machinery to ensure that constitutional safeguards for minorities are given effect to at both central and provincial levels. ${ }^{9}$ Patel informed the Assembly that these decisions expressed a general consensus of opinion

3 See, Hansard, 'India (Cabinet Mission)' House of Commons Debate (18 July 1946), vol. 425, para. 1423.

4 See, Constituent Assembly Debates: Official Report (hereinafter, CAD), vol. I (Delhi, 1946-1950), para. 1.5.10 (13 December 1946). The minority rights provision was also included in the ground rules for the Indian constitution set by a committee under the chairmanship of his father Motilal Nehru as early as 1928. The draft constitution is popularly known as the Motilal Nehru Constitutional Draft/Report, 1928. See, Neera Chandhoke, Contested Secessions: Rights, Self-determination, Democracy, and Kashmir (Oxford University Press 2012) 56.

$C A D$, vol. II, para. 2.15.13 (24 January 1947).

Ibid., para. 5.43.11 (27 August 1947).

Ibid., para. 5.43.12 (27 August 1947).

Ibid., para. 5.43.11 (27 August 1947).

Ibid., para. 5.43.13 (27 August 1947).

Page $\mid 268$ 
among Committee members, representing minority and majority communities. ${ }^{10}$

However, the Committee's proposed safeguards faced fierce and passionate challenge in the Assembly, based on the ideology of national unity. As a matter of fact, long before the Committee's proposals and as soon as the creation of Pakistan was decided, there was a sharp change in the mood of the Assembly regarding minority rights. As early as December 1946, M. R. Masani, despite his origin in a small minority community, argued before the Assembly for his vision of the national state:

[T] he conception of a nation does not permit the existence of perpetual or permanent minorities. Either the nation absorbs these minorities or, in course of time, it must break up. Therefore, while welcoming the clause in this Objective Resolution which promises adequate safeguards for the minorities, I would say that it is a good thing that we have these legal and constitutional safeguards, but that ultimately no legal safeguard can protect small minorities from the overwhelming domination of big masses, unless on both sides an effort is made to get closer and become one corporate nation, a homogeneous nation. ${ }^{11}$

The minority issue itself was seen as the root cause of India's partition. Therefore, the idea of any continuation of minority protection in postcolonial India was seen by P. S. Deshmukh as counterproductive and an essential threat to India's territorial and political integrity. ${ }^{12}$ Renuka Ray, likewise, asserted that 'we have stood helplessly while artificially this problem of religious differences - an echo of medieval times, has been fostered and nurtured and enhanced [...] Today we see as a result our country divided and provinces like [Bengal] dismembered. ${ }^{13}$ This view was shared by numerous other Assembly members, as the record of the debates reveals. ${ }^{14}$ Responding to the Muslim League members of the Assembly who were asking for more robust minority safeguards in the constitution in the form of a separate electorate, the Committee Chairman Patel himself concluded:

Those who want that kind of thing have a place in Pakistan, not here. Here, we are building a nation and we are laying the foundations of One Nation, and those who choose to divide again and sow the seeds of disruption will have no place, no quarter, here, and I must say that plainly enough.

The proposals of the Advisory Committee were finally adopted and reflected in the draft constitution. The Chairman of the Drafting Committee, B. R. Ambedkar, himself was a member of the depressed (dalit) community. While presenting the draft constitution before the Assembly for discussion, Ambedkar passionately argued that it was wrong for the majority to deny the existence of minorities, but it was equally wrong for the minority to perpetuate their own existence. Therefore, a solution had to be found

10 Ibid., para. 5.43.10 (27 August 1947). The opinion was, however, divided in the Assembly. See, ibid., para. 5.43.70-78 (27 August 1947).

$11 C A D$, vol. I, para. 1.7.4 (17 December 1946). Emphasis added.

$12 C A D$, vol. V, para. 5.43.28 (27 August 1947).

13 Ibid., para. 5.44.89 (28 August 1947).

14 See generally, ibid., para. 5.43.10-5.46.188 (27-30 August 1947). 
that would 'enable majorities and minorities to merge someday into one'. ${ }^{15}$

However, even this long-term strategy of offering safeguards to minorities for a limited period of time and simultaneously attempting to absorb them into the body politic of the national state soon appeared unworthy. With the bitter experience of communal violence following the Partition, mass migration, the treatment of Hindu and Sikh minorities in Pakistan, and more importantly, with the consolidation of political power, the nationalist ruling elites in India decided to revisit the whole question of minority protection. Accordingly, in a sudden dramatic move, the Advisory Committee reopened the question of minority rights and concluded in its final report of May 1949 that there should be no provision in the constitution for the reservation of seats for any religious minorities. Such protection, however, would remain for various tribal groups and the scheduled caste Hindus ${ }^{16}$ - but on the ground of economic and social backwardness; none of these groups was treated as a minority. ${ }^{17}$ As the tribal leader Jaipal Singh asserted during Assembly debates, 'a group of people who are the original owners of this country, even if they are only a few, can never be considered a minority'. ${ }^{18}$

As a matter of fact, it is quite clear from the Assembly debates on this issue that with only a handful of exceptions, the representatives of the Muslim and Sikh communities in the Assembly (other, smaller communities never asked for a reservation of seats) by that time preferred to leave the matter to the goodwill of the majority. ${ }^{19}$ Begum Aizaz Rasul specifically stated this in the following words:

To my mind it is very necessary that the Muslims living in this country should throw themselves entirely upon the good-will of the majority community, should give up separatist tendencies and throw their full weight in building up a truly secular state. ${ }^{20}$

Sardar Patel, as the Chairman of the Committee, responded: 'the future of a minority, any minority, is to trust the majority. If the majority misbehaves, it will suffer. ${ }^{21}$ And taking part in the debate on this change of position on minorities, Prime Minister Nehru reminded his audience of the primacy of the national integration that must not be disturbed by any separatist tendency in the name of communalism or provincialism. ${ }^{22}$

Nevertheless, to the surprise of Muslims and Sikhs, all other remaining safeguards in the draft report - including the provisions for reservations of public jobs and the provision for a mechanism for implementing minority protection - were also scrapped for all minorities while the same safeguards remained for the scheduled castes, tribal

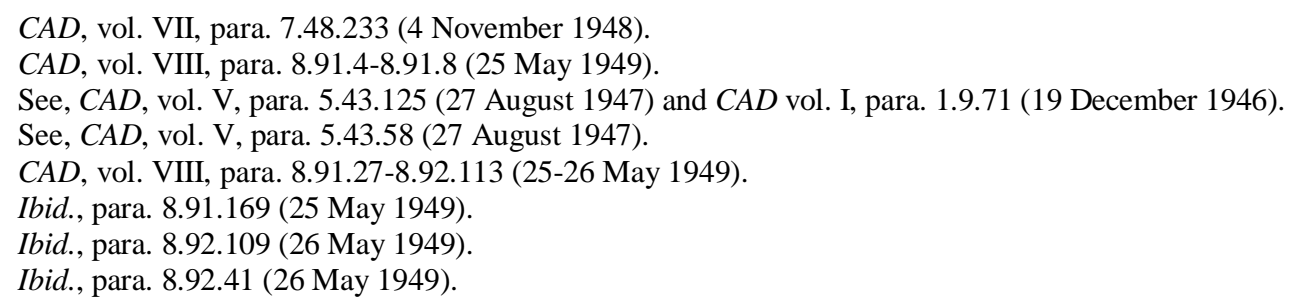

Page | 270 
communities, and in some cases, for Anglo-Indian communities. ${ }^{23}$ This, of course, elicited heated debates and fierce criticism from the representatives of the Muslim and Sikh communities, who claimed that no prior consensus had been secured on these questions. ${ }^{24}$ In an angry response, the Sikh member Hukam Singh commented that 'this nationalism is an argument for vested interests. Even the aggressiveness of the majority would pass off as nationalism, while the helplessness of the minority might be dubbed as communalism. ${ }^{25}$ It was, however, confirmed by one of the members of the Committee, K. M. Munshi, that:

at the time when the Advisory Committee met on the last occasion, there was no question of providing safeguards for any religious minority. The negotiations proceeded on the footing that except the backward classes who are economically and socially backward, and the Scheduled Castes and Tribes who have a special claim of their own, no other minority should be recognised in the Constitution. ${ }^{26}$

Despite Ambedkar's strong voice for minority rights previously ${ }^{27}$ on this occasion he was content with the protection of his own community of the scheduled castes. On 16 November 1949, a motion was proposed to remove any mention of 'minorities' even from the titles of relevant parts of the constitution and replace the word 'minorities' with 'certain classes'. The motion was enthusiastically adopted. As the Assembly member Ajit Prasad Jain succinctly put it, while reflecting on the success of the new constitution in dismantling the colonial architecture of minority protection, '[m]ay be that we have not so far succeeded in establishing a fully united and harmonious society, but much of the old rancour has disappeared and we are on the path of achieving a real national unity'.28

In this way, the ideology of the postcolonial 'national' state suppressed the issue of minority protection, despite the initial recognition by the ruling elites of the importance of this issue. Through the modes of operation of legitimation, dissimulation, and unification, the ideology of the national state offered necessary justification for adopting a nationalist constitutional mould that had no place for minorities. With the salience of the nation-state form as the dominant norm for postcolonial statehood, the ideology of the postcolonial 'national' state also reified such marginalisation of minorities as an obvious historical destiny of minorities in the normal course of nationbuilding. Thus, the ideology of the postcolonial 'national' state, manifested through a series of ideological modes of operation, is intrinsically connected to the process by

\footnotetext{
$C A D$, vol. X, para. 10.151.4 (14 October 1949).

See, ibid., para. 10.151.10-10.151.193 (14 October 1949).

${ }^{25}$ Ibid., para. 10.151 .38 (14 October 1949).

Ibid., para. 10.151.256 (14 October 1949).

27 Cf. CAD, vol. III, para. 3.20.260 (1 May 1947). See also, B. R. Ambedkar, States and Minorities: What are Their Rights and How to Secure them in the Constitution of Free India (1947), Memorandum on the Safeguards for the Scheduled Castes submitted to the Constituent Assembly on behalf of the All India Scheduled Castes Federation, available at Vasant Moon (com), Dr. Babasaheb Ambedkar: Writings and Speeches, vol. I (New Delhi: Dr. Ambedkar Foundation, 2014 [1979]), 381-449. 
which homogeneous national states are made. The making of the postcolonial 'national' state leads to the marginalisation of various minority groups, for these minorities often find themselves on the wrong side of state boundaries and under the jurisdiction of hostile 'national', yet majoritarian, states.

\section{THE POSTCOLONIAL 'LIBERAL' STATE}

Even as the vision of the 'national' state - a homogeneous nation within a defined territory - served as an ideology in dealing with minorities, such a national state affirmed the ideological vision of its internal political organisation. After all, when the postcolonial national state dismantles the ethno-religious underpinning of minority groups on grounds of national integration, it needs to find for itself a 'neutral' and apparently 'non-majoritarian' philosophical outlook. The predominance of the liberal worldview of the post-WWII international order provided the necessary ideological foundation for many postcolonial states and their constitutional architecture. This ideology of the postcolonial 'liberal' state also justified the omission of any specific minority group protection in the constitutions of these postcolonial states, thereby reducing minority groups to individual units of citizenry. In other words, the ideology of the postcolonial 'liberal' state worked through the ideological mode of operation of fragmentation.

In the Indian context, the ideology of the liberal state is expressed primarily in 'egalitarianism' and 'secularism'. The Indian nation was essentially conceived as a political community united by its commitment to the common political ideals of secularism, democracy, rights, equality, and justice. ${ }^{29}$ In this political imagination, minority rights naturally appeared as a distraction - something with the potential to undercut the liberal values that the postcolonial Indian state was set to be defined by. Given that citizenship in the postcolonial liberal state was characterised primarily by equal individual rights, the proposition of safeguarding minorities was deemed inappropriate as 'it was thought to compromise its commitment to not discriminate between its citizens on the basis of their caste, creed or community'. ${ }^{30}$ The addition of secularism to this liberal egalitarianism made it normatively even more unreasonable to concede special rights to religious minorities.

Pandit Govind Ballabh Pant represented the liberal vision of the postcolonial Indian state most succinctly during the Constituent Assembly debates. Criticising the "morbid tendency' in Indian politics to highlight communities in political arrangements, Pant reminded the Assembly that the individual citizens constitute the backbone of the state. It is citizens that form communities, and 'the individual as such is essentially the core of all mechanisms and means and devices that are adopted for securing progress and advancement' ${ }^{31}$ Long before the provisions for minority rights were hastily removed

29 Rochana Bajpai, 'Minority Rights in the Indian Constitutional Assembly Debates, 1946-1950' (2002) Queen Elizabeth House Working Paper Series, University of Oxford, 30, 12-13. See also Shabnum Tejani, 'Between Inequality and Identity: The Indian Constituent Assembly and Religious Difference' (2013) 33(3) South Asia Research 205-221.

31 CAD, vol. II, para. 2.15 .24 (24 January 1947).

Page $\mid 272$ 
from the draft constitution, Damodar Swarup Seth questioned the legitimacy of constitutional protection of religious minorities in a secular state:

[I]n a secular state minorities based on religion or community should not be recognised. If they are given recognition then I submit that we cannot claim that ours is a secular state. Recognition of minorities based on religion or community is the very negation of secularism. ${ }^{32}$

Sardar Patel echoed the vision of secular India when he informed the Assembly of the removal of all safeguards for religious minorities: 'this Constitution of India, of free India, of a secular India will not hereafter be disfigured by any provision on a communal basis'. ${ }^{33}$

When the provisions for reservations for minorities were finally removed from the constitution, R. K. Sidhva, as a member of the minority Parsee community, described the occasion as a moment of historic victory and national pride, given that Indian constitution has 'kept no room for communalism and that we are in the true sense of the word a secular State'. ${ }^{34}$ A number of other members of the Assembly from all religious backgrounds celebrated the secular nature of the constitution, although a handful of speakers did regret the absence of any clear recognition of religious minorities in the constitution. ${ }^{35}$ The Assembly member Ajit Prasad Jain summarised the liberal position of the Indian constitution vis-à-vis minorities in the following words:

The minorities have been guaranteed freedom of religion and freedom to develop their culture, language and script, but in matters of political rights, there is no discrimination either in their favour or against them. The minorities therefore should have nothing to fear or be apprehensive about their future. It is in that sense that we have established what is popularly known as a secular State. $^{36}$

Thus, with this liberal vision of secular India, all references to religious minorities were removed from the constitution. The only groups that were given some protection were the scheduled castes and scheduled tribes. As noted in the preceding section, these two groups were not treated as minorities; the protection was offered on the basis of their socio-economic backwardness. The Anglo-Indian community was also allowed to continue with the privileges they happened to enjoy under the British rule, but it was argued that they were not a religious community and, hence, this exception did not challenge the secular nature of the Indian state.

The constitutional secular ideology of the Indian nation faced a different challenge when it came to the Hindu nationalist demand for cow protection. Throughout the

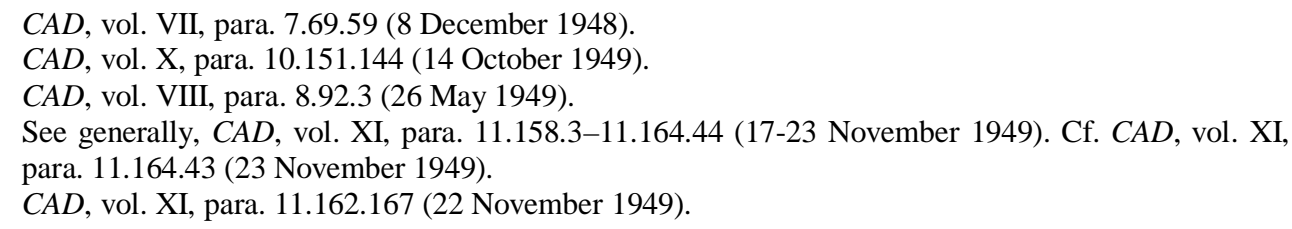


nineteenth and early twentieth centuries, cow protection was an issue of grave concern in Hindu nationalist politics and in the communal tension between the Hindu and Muslim communities. Against that backdrop, during the Constituent Assembly debates, demands were made for specific constitutional provisions protecting the cow. ${ }^{37}$ As late as 1948, Thakur Das Bhargava demanded a constitutional guarantee that the state shall endeavour to modernise agriculture and animal husbandry and shall take steps for preserving and improving the breeds of cattle and prohibit the slaughter of cow and other useful cattle. ${ }^{38}$

Although in his demand Bhargava relied mainly on an economic case for prohibiting cow slaughter, ${ }^{39}$ in the Assembly discussion on the proposal, a number of members specifically highlighted the religious impetus behind the need for cow protection. Seth Govind Das, for example, added religious and cultural grounds to the economic case and demanded a prohibition on the slaughter of cows of any age and kind. Identifying 'cow protection' as a majoritarian Hindu and therefore Indian cultural issue, along with questions of national language, national script, and national anthem, he argued that 'Swaraj' - self-rule - would have no meaning to people without protection for this culture. ${ }^{40}$ Similarly, acknowledging the religious aspect of 'cow protection', Shibban Lal Saxena argued that if thirty crores of the Indian population - that is, three hundred million - feel that this cow protection should be incorporated in the laws of the country, the Assembly should not ignore this simply because it is a religious issue. ${ }^{41}$ That view was shared by Raghu Vira Dhulekar, who even claimed:

Our Hindu society, or our Indian society, has included the cow in our fold. It is just like our mother. In fact it is more than our mother. I can declare from this platform that there are thousands of persons who will not run at a man to kill that man for their mother or wife or children, but they will run at a man if that man does not want to protect the cow or wants to kill her. ${ }^{42}$

As ideas of the Hindu society and the Indian nation thus merged, Muslim League representatives in the Assembly took the issue of cow protection as a useful tool for exposing the ambivalence of the liberal secular rhetoric that was flying high in the Assembly to deny concessions to religious minorities. Z. H. Lari, for example, urged the majority make their demand in clear religious terms and asserted that the Muslim minorities would respect that demand, given that Islam did not specifically require the sacrifice of cows. ${ }^{43}$ Syed Muhammad Saadulla, too, expressed his sympathy with the Hindu majority demand for cow protection as a religious matter and advised the majority to "come out in the open and say directly that " $[\mathrm{t}] \mathrm{his}$ is part of our religion. The cow should be protected from slaughter and therefore we want its provision either

\footnotetext{
See, $C A D$, vol. V, para. 5.46 .44 (30 august 1947); $C A D$, vol. VII para. 7.49 .81 (5 November 1948).

1. $38 \quad C A D$, vol. VII, para. 7.59 .85 (24 November 1948).

2. $39 \quad$ Ibid., para. 7.59 .92 (24 November 1948).

40 Ibid., paras. 7.59.102-1010 (24 November 1948).

3. ${ }^{41} \quad$ Ibid., para. 7.59.136 (24 November 1948).

$42 \quad$ Ibid., para. 7.59.148 (24 November 1948).

43 Ibid., para. 7.59.151-153 (24 November 1948).
}

Page | 274 
in the Fundamental Rights or in the Directive Principles", but condemned those, who, in his opinion, put the question on the economic front and thereby attempted to satisfy the ingrained Hindu feeling against cow slaughter by the backdoor. ${ }^{44}$

Bhargava's proposal was finally adopted. The Constitution of India indeed declares, as one of the directive principles of the state, that measures will be taken to prohibit the slaughter of cows. ${ }^{45}$ Paradoxically, according to the US Department of Agriculture, India is currently the fourth-largest beef-exporting country in the world. ${ }^{46}$ In contrast, a total of 63 cow vigilante attacks by Hindu fundamentalists occurred in India between 2010 and mid-2017, which saw 28 Indians (24 of them Muslims) killed and 124 injured. ${ }^{47}$ Cow vigilante activities increased sharply after Narendra Modi's government, with its Hindutva ideology, came to power in 2014, but as the preceding discussion reveals, even the 'secular' constitution could not avoid some sort of accommodation for cow protection.

Also, in line with liberal egalitarian philosophy, special protection for the scheduled castes and scheduled tribes was explained only as a transitional measure, available for a limited period of time. This is a classic liberal dilemma with any deviation - as, for example, in affirmative action policies - from the principle of equality and nondiscrimination. Hence, by definition all such policies have to be temporary and transitional: as soon as the group members in question achieve equality with the rest of the society, such special measures need to end. This solution makes affirmative action policies normatively coherent with the liberal core values of equality and nondiscrimination. The time-limited safeguards that the Indian constitution grants to the tribal communities and the scheduled castes follow this logic and simultaneously underscore the liberal underpinning of the internal political organisation of the postcolonial state. When members of the assembly asked for better protection for the tribal communities in India, Sardar Patel expressed his frustration thus:

Is it the intention of people to defend the cause of the tribals to keep the tribes permanently in their present state? [...] I think that it should be our endeavour [...] not keep them as tribes, so that, 10 years hence, when the Fundamental Rights are reconsidered, the word 'tribes' may be removed altogether, when they would have come up to our level. It is not befitting India's civilization to provide for tribes. ${ }^{48}$

The liberal agenda of 'progress' and assimilation can hardly be ignored here.

\footnotetext{
Ibid., para. 7.59.154-157 (24 November 1948).

See, the Constitution of India 1952, Art 48.

46 Katharina Buchholz, 'The Biggest Exporters of Beef in the World' (Statista, 27 April 2021) <https://www.statista.com/chart/19122/biggest-exporters-of-beef/> accessed 24 November 2021.

47 Tommy Wilkes and Roli Srivastava, 'Protests held across India after attacks against Muslims' (Reuters, 28 June 2017) <https://www.reuters.com/article/india-protests-idINKBN19J2C3> accessed 26 February 2021.

$48 C A D$, vol. III, para. 3.19.152 (30 April 1947).
} 


\section{CONCLUSION}

The foregoing story about how the vision of the postcolonial Indian state as discussed in the Constituent Assembly debates shaped the normative position of minorities in the Indian constitution is not peculiar to India. A close reading of Bangladeshi Constituent Assembly debates equally exposes the way ethnic minority groups have been marginalised in the process of creating the 'national' and 'liberal' Bangladeshi state and also how such marginalisation has been legitimised in the name of national unity and the liberal principles of equality and non-discrimination. ${ }^{49}$

Thus, a critical examination of the postcolonial state as an ideology reveals how it serves to establish and sustain relations of domination by the political majority over vulnerable minority groups through a number of modes of ideological operation. In the anticolonial nationalist discourse and the political imagination of the postcolonial order, the vision of the postcolonial state appeared as the natural and obvious choice. This ideological operation of reification by the postcolonial state essentialised the 'state-form' so far as the political emancipation of the colonial state was concerned. Closely related to this phenomenon is the ideological mode of legitimation, and the postcolonial state operated vis-à-vis minorities within that mode too. Once established as the only legitimate outcome of decolonisation, the relations of domination between the majority and the minority become perpetual. Similarly, at the micro level, the ideology of the national state relied on unification as a mode of operation, while the ideology of the liberal state depended on fragmentation - diffusing minority groups into liberal individual citizens of the hostile state. In other words, a critical examination of the postcolonial state as an ideology helps us understand how the visions of the postcolonial 'national' and 'liberal' state establish and sustain asymmetric power relations to marginalise minorities in these states but at the same time justify and gloss over such marginalisation.

\footnotetext{
${ }^{49}$ For details, see Shahabuddin, Minorities and the Making of Postcolonial States in International Law (Cambridge University Press 2021) 121-136, 186-195.
}

Page $\mid 276$ 
